\title{
Health literacy of patients with hypertension and diabetes in a northern region of Portugal
}

Literacia em saúde de utentes com hipertensáo e diabetes de uma regiáo do norte de Portugal Alfabetización en salud de usuarios con hipertensión y diabetes en una región del norte de Portugal

Isabel Maria Batista de Araújo*(D); Rui Alberto Ferreira Jesus**(D); Maria de Lurdes Teixeira***(D);

Ana Rita Santos Cunha***; Fernando Miguel da Silva Santos*****; Sílvia Raquel Fernandes Miranda******

\begin{abstract}
Background: Health Literacy (HL) is a concept that can be analyzed in 3 domains: health promotion, disease prevention and health care.

Objective: Describe HL level of a group of patients with hypertension and diabetes in a northern region of Portugal.

Methodology: Cross-sectional descriptive-exploratory study. Sample of convenience, with 401 users of a cluster of health centers in the northern region of Portugal. Data were collected after informed consent of the users, through a survey with the LS assessment scale European Health Literacy Survey (HLS-EU-PT), translated and validated into Portuguese. Descriptive and inferential statistics techniques were used, using SPSS, version 24.

Results: Users presented an inadequate or problematic level of HL. These considered the doctor and the nurse as the professionals who can improve their HL level.

Conclusion: Low HL level is a problem for health management, it is important to focus on a strategy to increase $\mathrm{HL}$ in chronic disease patients.
\end{abstract}

Keywords: health literacy; diabetes mellitus; hypertension; chronic disease

\section{Resumo}

Enquadramento: A literacia em saúde (LS) é um conceito que pode ser analisado em 3 domínios: promoção da saúde, prevenção da doença e cuidados de saúde.

Objetivo: Descrever o nível de LS de um grupo de utentes com hipertensão arterial e diabetes de uma região do norte de Portugal.

Metodologia: Estudo descritivo-exploratório transversal. Amostra de conveniência com 401 utentes de um agrupamento de centros de saúde da região norte de Portugal. Recolheram-se dados após consentimento informado dos utentes, através de um inquérito com a escala de avaliação de LS, European Health Literacy Survey (HLS-EU-PT), traduzida e validada para Portugal. Utilizaram-se técnicas da estatística descritiva e inferencial, com recurso ao software IBM SPSS Statistics, versão 24. Resultados: Os utentes apresentavam um nível inadequado ou problemático de LS e consideraram o médico e o enfermeiro como os profissionais que podem melhorar o seu nível de LS.

Conclusáo: Níveis baixos de LS são um problema para a gestão em saúde, pelo que urge apostar numa estratégia para aumentar a LS nos utentes com doenças crónicas.

Palavras-chave: alfabetização em saúde; diabetes mellitus; hipertensão; doença crónica

*Ph.D., Principal Adjunct Professor, School of Health of Vale do Ave - CESPU, 4760-409, Vila Nova de Famalicão, Portugal [isabel.araujo@ipsn.cespu.pt].(D) https://orcid.org/0000-0001-5143-4237.Conde Famalicáo, Portugal isabel.araujo@ipsn.cespu.pt..E https://Orcid.orgy0000-0001-5143-4237. Con-
tribution to the article: literature search, methodology, and article writing. Address for correspondence: tribution to the article: literature search, methodology, and article writing
Rua José António Vidal, $81,4760-409$, Vila Nova de Famalicão, Portugal.

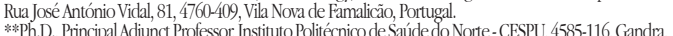
Portugal [rui.jesus@ @ipsn.cespu.pt]. O h https:///orcid.org/0000-0003-4224-1526. Contribution to the artiPortugal [rui.jesus@ipsn.cespu.pt].@B.
cle: statistical treatment and assessment.

cle: statistical treatment and assessment. dra, Portugal [mlurdes.teixeira@ipsn.cespu.pt]. (O) htps://orcid.org/0000-0003-4008-6315. Contribu-

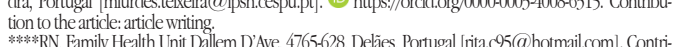
bution to the article: literature search and data collection.

bution to the article: literature search and data collection.

the article: literature search and data collection.
$* * * * * *$ RN, Family Health Unit Dallem D'Ave, 4765-628, Delães, Portugal [silvia_811_@ @hotmail.com]. Contribution to the article: literature search and data collection.

Revista de Enfermagem Referência

\section{Resumen}

Marco contextual: La alfabetización en salud (AS) es un concepto que se puede analizar en tres ámbitos: promoción de la salud, prevención de la enfermedad y asistencia sanitaria.

Objetivo: Describir el nivel de AS de un grupo de usuarios con hipertensión y diabetes en una región del norte de Portugal.

Metodología: Estudio descriptivo-exploratorio transversal. Muestra de conveniencia de 401 usuarios de un agrupamiento de centros de salud en la región norte de Portugal. Los datos se recogieron, después de obtener el consentimiento informado de los usuarios, a través de una encuesta con la escala de evaluación de AS, la European Health Literacy Survey (HLS-EU-PT), traducida y validada para Portugal. Se utilizaron técnicas de estadística descriptiva e inferencial, para lo cual se recurrió al software IBM SPSS Statistics, versión 24.

Resultados: Los usuarios presentaron un nivel inadecuado o problemático de AS y consideraron al médico y al enfermero como los profesionales que pueden mejorar su nivel de AS.

Conclusión: Los niveles bajos de AS son un problema para la gestión de la salud, por lo que es necesario apostar por una estrategia para aumentar la AS en los pacientes con enfermedades crónicas.

Palabras clave: alfabetización en salud; diabetes mellitus; hipertensión; enfermedad crónica

Received for publication: 05.03 .18

Accepted for publication: 22.06.18

Série IV - n. ${ }^{0} 18$ - JUL./AGO./SET. 2018 


\section{Introduction}

Health promotion (HP) contributes to reducing the risk of developing diseases, especially through the promotion of healthy lifestyles. One of the strategies for HP is health education which aims at health improvement, disease prevention, rehabilitation or adaptation to a new life condition. Health education empowers people to care for their health project, that is, it provides them with knowledge, skills, and abilities to improve their quality of life and, in this way, be responsible for their health and the health of those surrounding them (Salazar, Crosby, \& DiClemente, 2015). A good level of health literacy (HL) is required to monitor one's health status and make prevention-related decisions. In fact, studies have shown that $\mathrm{HL}$ is a key variable in surveillance, monitoring, and control of diseases in general and chronic diseases in particular, such as hypertension (HT) and diabetes mellitus (DM). This study was conducted in line with the National Program for Health Education, Literacy and Self-care, which was created by the $21^{\text {st }}$ Constitutional Government of Portugal (Despacho n. ${ }^{\circ}$ 3618-A/2016 de 10 de março). The purpose of this study was to assess the HL level of patients with HT or DM in a northern region of Portugal.

\section{Background}

HL is a multidimensional concept with three key domains: (i) healthcare; (ii) disease prevention, and (iii) health promotion. The first domain - healthcare - is defined as the ability to access information on health issues and understand, interpret and evaluate it to make decisions on these issues. The domain of disease prevention is defined as the ability to access information on risk factors for health, in order to understand, interpret and evaluate them to make decisions to protect one's own health. Finally, HP is defined as the ability to identify determinants of health in the social and physical environment, understand the influence of contextual variables on individual or family health, as well as act on them in order to reduce their harmful effects. HL also has four levels of information processing for the deci- sion-making process: access, understand, appraise, and apply (Soares et al., 2013; Sørensen et al., 2012).

In recent years, the importance of HL has been widely recognized, both in academic circles and in the centers of decision-making and planning of health policies, and it has become a theoretical concept that is being constantly redefined and reinvented. HL is currently seen as a complex set of skills, such as reading and acting on written health information, communicating needs to health professionals, and understanding the professionals' instructions. HL level is not a trait, but rather a state which partly reflects each person's experience of their health/disease process, their predominant communication style with the medical community in the healthcare system (Peterson et al., 2011). Studies have shown that a person with a sufficient/excellent HL level is more likely to be able to make health decisions in the context of their family and community (Sørensen et al., 2012). Recent studies have found that higher HL levels lead to lower healthcare costs, increased health knowledge, less frequent use of health services, and shorter hospital stays (Sørensen et al., 2012).

Low HL levels are associated with a greater difficulty in managing the health project, understanding and following health professionals' instructions, and understanding information leaflets. As service users, people with low HL levels tend to seek healthcare services less often for the purposes of health promotion and disease prevention, have shorter hospitalizations, and usually have complications associated with poorly controlled chronic diseases (Direção-Geral da Saúde [DGS], 2016). Other studies emphasize that people suffering from chronic diseases should receive specific interventions because they are expected to adequately control their disease and prevent complications (Pereira, Costa, Sousa, Jardim, \& Zanini, 2012). Moreover, evidence shows that low HL levels are a risk factor for several diseases, including cardiovascular and endocrine diseases (Santos, 2010). According to Statistics Portugal (Instituto Nacional de Estatística [INE], 2011), it is estimated that $40.5 \%$ of the population living in Portugal (approximately $2,875,000$ people) aged 15 to 64 years suffered from health problems or chronic diseases. 
As shown above, HL plays a decisive role in the management, control, and prevention of diseases in general. However, it is even more important in some diseases, either due to their level of chronicity or the broad spectrum of effects on patients' daily lives. The most worrying diseases are DM and HT (DGS, 2016). Global estimates indicate that 382 million people live with DM, a number which is expected to rise to 592 million by 2035 (International Diabetes Federation, 2013). In Portugal, 3 million people suffer from HT, that is, one in every three people (Serra, 2016). Available evidence shows that the HL level is inadequate or problematic in different contexts and/or with different participant profiles (Kale et al., 2015; Edwards, Wood, Davies, \& Edwards, 2015).

\section{Research question}

What is the HL level of patients with DM or HT of a cluster of healthcare centers (Agrupamento de Centros de Saúde, ACeS) in a northern region of Portugal?

\section{Methodology}

Under the quantitative paradigm, a cross-sectional, exploratory, descriptive study was conducted. Data were collected between December 2016 and February 2017 in a ACeS in a northern region of Portugal. The convenience sample was composed of 401 patients of a total of 13,842 users registered in that ACeS. The following inclusion criteria were applied: having DM or HT; being 18 years of age or over; and attending nursing consultations for people with DM or HT.

A questionnaire was applied which was divided into three groups. Group 1 was composed of sociodemographic questions (gender, age, education level, marital status, and professional activity). Group 2 included questions to determine the HL level, using the European Health Literacy Survey (HLS-EU-PT; Sørensen et al., 2012), which was translated and validated in Portugal by Pedro, Amaral, and Escoval (2016). The answers ranged from 1 to 5 in which 1 means very difficult, 4 very easy, and 5 do not know/no answer. The study focused mainly on the HL variable, which integrates three health domains: Healthcare (16 items); Health promotion (15 items); and Disease prevention (16 items). The standardized values for the scale ranged from a minimum of zero to a maximum of 50 , where zero represents the worst HL level and 50 the best HL level. The scale also allows dividing HL levels into categories, which are classified as inadequate, problematic, sufficient, and excellent (Think Tank Capacitação do Cidadão em Saúde, 2015). Group 3 included the clinical variables (disease and which was the health professional who most contributed to increasing the HL level). This instrument was applied in the form of a survey.

Permission was requested from and granted by the ethics committee of the Northern Regional Health Administration (Opinion No. 101/2016). Then, a meeting was held with the coordinators of three family health units (Unidade de Saúde Familiar, USF). The project was presented and each USF was asked to collaborate in the identification of potential participants. Each USF provided a private room for data collection. During the consultations, patients were invited to participate in the study. They signed an informed consent form and were ensured anonymity and data confidentiality. After data collection, each questionnaire was coded with a number and a letter. Data were analyzed using descriptive and inferential statistics via IBM SPSS Statistics, version 24. Statistical tests (chi-square test and $t$-test) were performed with a 5\% significance level.

\section{Results}

Taking into account the objective of the study, descriptive results will be presented first and then the results of the bivariate analysis.

\section{Sample characterization}

This study had the participation of 401 patients of a ACeS: 192 (47.88\%) men and $209(52.12 \%)$ women. Patients' ages ranged from 22 to 92 years, with a mean age of 62.3 years. In relation to marital status and professional activity, as shown in Table 1 , most of them were married $(308 ; 76.81 \%)$ and retired $(230 ; 57.36 \%)$. Most of the participants (329; $82.05 \%$ ) had only completed basic education. 
Table 1

Sociodemographic characteristics of patients with DM or HT of a cluster of healthcare centers in a northern region of Portugal.

\begin{tabular}{|c|c|c|c|c|}
\hline Variables & No. of individuals & Percentage (\%) & Age mean & $\begin{array}{l}\text { Standard } \\
\text { deviation }\end{array}$ \\
\hline \multicolumn{5}{|l|}{ Gender } \\
\hline Male & 192 & $47.88 \%$ & \multirow{2}{*}{62.3} & 11.5 \\
\hline Female & 209 & $52.12 \%$ & & 12.5 \\
\hline \multicolumn{5}{|l|}{ Age in categories } \\
\hline Adult & 218 & $54.36 \%$ & & \\
\hline Elderly & 183 & $45.64 \%$ & & \\
\hline \multicolumn{5}{|l|}{ Marital status } \\
\hline Single & 17 & $4.24 \%$ & & \\
\hline Married & 308 & $76.81 \%$ & & \\
\hline Cohabiting & 9 & $2.24 \%$ & & \\
\hline Widowed & 52 & $12.97 \%$ & & \\
\hline Divorced & 15 & $3.74 \%$ & & \\
\hline \multicolumn{5}{|c|}{ Education level in categories } \\
\hline No education level & 35 & $8.73 \%$ & & \\
\hline Basic education & 329 & $82.05 \%$ & & \\
\hline Secondary education & 26 & $6.48 \%$ & & \\
\hline Higher education & 11 & $2.74 \%$ & & \\
\hline \multicolumn{5}{|l|}{ Professional activity } \\
\hline Employed & 126 & $31.42 \%$ & 51.26 & 7.365 \\
\hline Unemployed & 38 & $9.48 \%$ & 53.18 & 9.226 \\
\hline Retired & 230 & $57.36 \%$ & 70.11 & 7.928 \\
\hline Other & 7 & $1.74 \%$ & 51.57 & 8.384 \\
\hline
\end{tabular}

\section{Health literacy}

With regard to HL, 172 (42.9\%) patients had a problematic HL level, while 162 (40.4\%) patients had an inadequate HL level.

Figures 1, 2, and 3 summarize the 47 items of the HLS-EU-PT, divided into its three domains: Healthcare, Disease prevention, and
Health promotion, respectively. Light-colored items are those in which the patients reported less difficulty, such as following the instructions from the doctor or pharmacist. Dark-colored items correspond to those in which the patients reported having more difficutly to accomplish. 


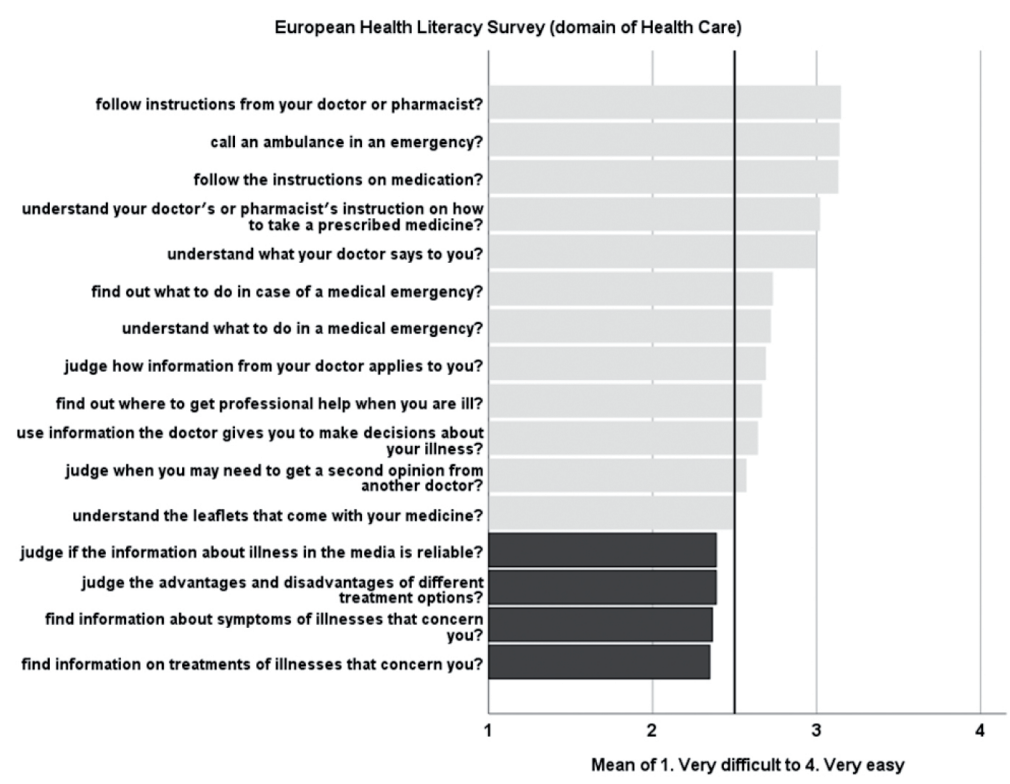

Figure 1. Mean HL levels of a group of patients with HT or DM, in Portugal, in the domain of Healthcare.

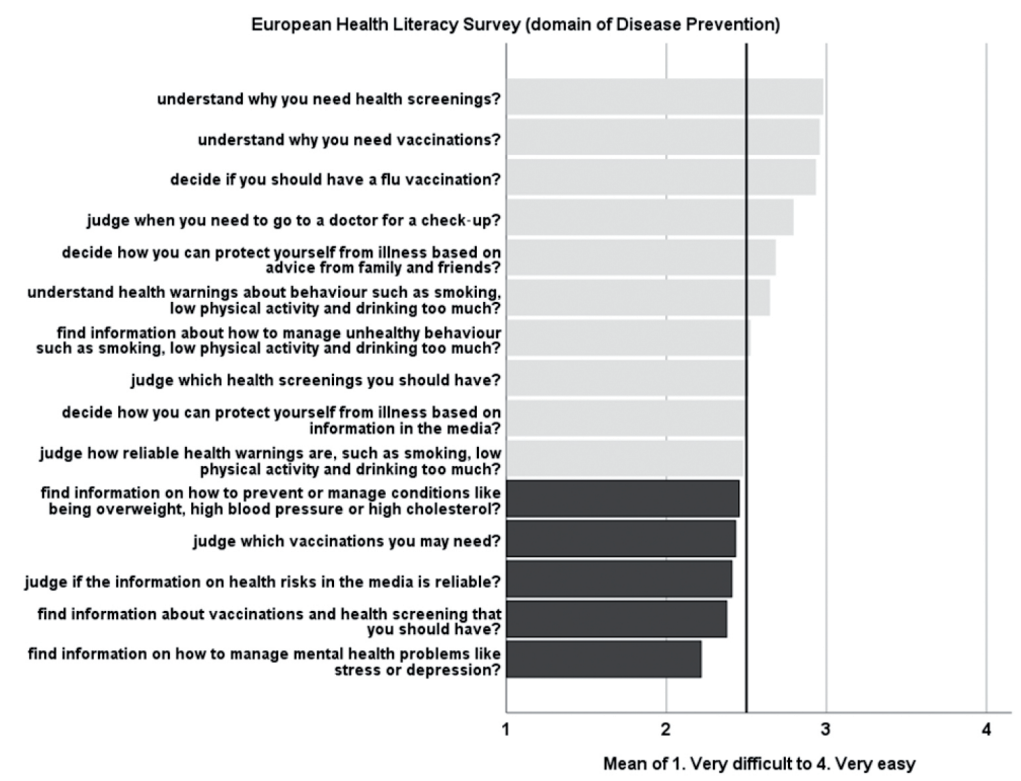

Figure 2. Mean HL levels of a group of patients with HT or DM, in Portugal, in the domain of Disease prevention. 


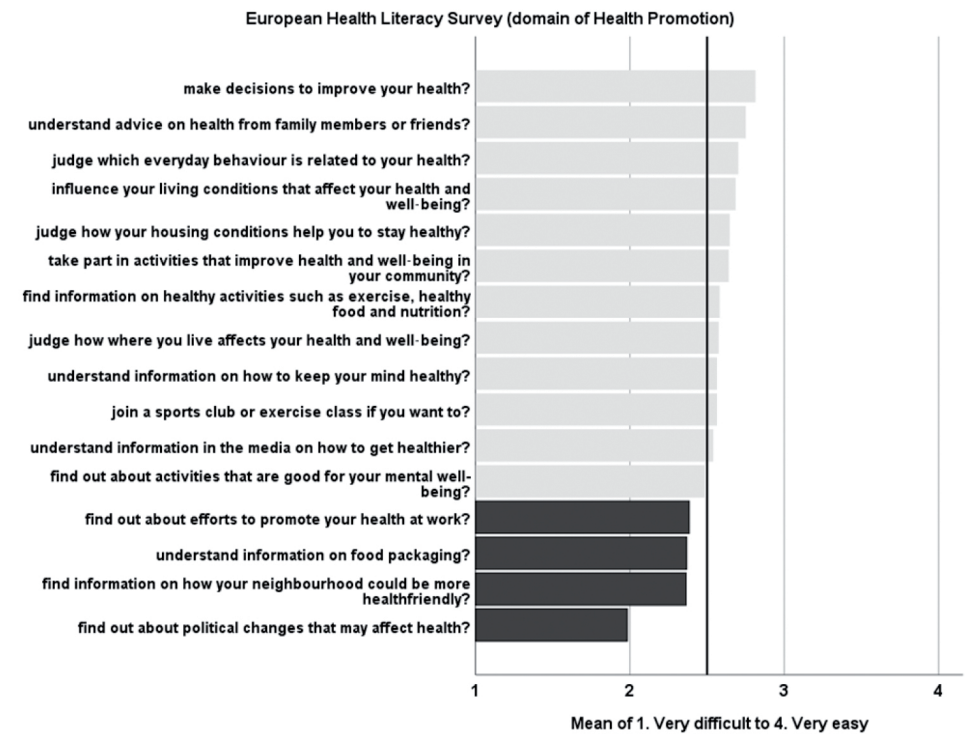

Figure 3. Mean HL levels of a group of patients with HT or DM, in Portugal, in the domain of Health promotion

As regards the different domains of the scale (Health care, Disease prevention, and Health promotion), as can be seen in Figure 4, all respondents had an inadequate HL level, with the exception of the Healthcare domain, where the majority of patients had a problematic HL level.
All domains were directly proportional to the overall HL level, which means that whenever the level of a domain increases, the overall HL level will also increase, and vice versa. The different domains are interdependent.

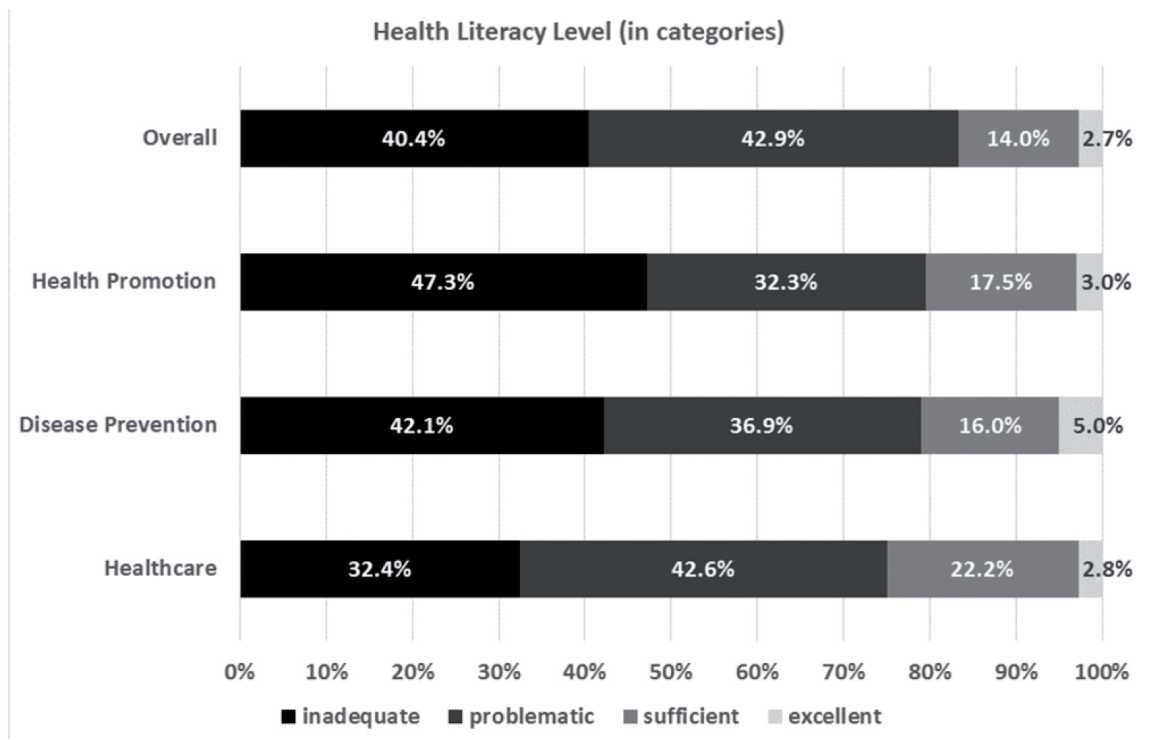

Figure 4. HL level in the different domains of the HLS-EU-PT, in a group of patients with HT or DM, in Portugal. 
Clinical variables

In relation to the clinical variables, Table 2 shows that patients being monitored or fol- lowed-up in a consultation showed a higher overall HL level than those who were not followed-up in health units.

Table 2

Clinical variables of patients with DM or HT, of a cluster of healthcare centers in a northern region in Portugal.

\begin{tabular}{|c|c|c|c|}
\hline Variables & No. of individuals & Percentage (\%) & HL Level (mean) \\
\hline \multicolumn{4}{|c|}{ Follow-up consultation } \\
\hline Yes & 66 & $16 \%$ & 26.5 \\
\hline No & 332 & $82.8 \%$ & 26.3 \\
\hline \multicolumn{4}{|c|}{ Another disease } \\
\hline Yes & 171 & $41.3 \%$ & 25.8 \\
\hline No & 226 & $54.6 \%$ & 26.9 \\
\hline \multicolumn{4}{|c|}{$\begin{array}{l}\text { Professional who contributed the most to } \\
\text { increasing the HL level }\end{array}$} \\
\hline Physician & & & 26.7 \\
\hline Nurse & & & 26.6 \\
\hline Other & & & 0 \\
\hline \multicolumn{4}{|c|}{ Used PHC in the past 6 months } \\
\hline Yes & 346 & $87.1 \%$ & 6.1 \\
\hline No & 41 & $12.9 \%$ & 28.2 \\
\hline \multicolumn{4}{|c|}{ Patient with DM } \\
\hline Yes & 184 & $45.9 \%$ & 25.6 \\
\hline No & 217 & $54.1 \%$ & 27.1 \\
\hline \multicolumn{4}{|c|}{ Patient with HT } \\
\hline Yes & 339 & $84.5 \%$ & 26.1 \\
\hline No & 62 & $14.5 \%$ & 27.8 \\
\hline
\end{tabular}

The overall HL level was slightly higher in the respondents who reported not having any disease (besides DM and HT).

\section{Discussion}

The sample was composed mostly of women, married, with a mean age of 62 years, basic education, retired, with HT or DM, and with problematic or inadequate HL levels. This study corroborates the profile found in other Portuguese studies on HL (Costa, Saboga-Nunes, \& Costa, 2016; Espanha, Ávila, \& Mendes, 2016; Pedro et al., 2016).

The analysis of HL based on its different domains showed an inadequate level in the domains of Disease prevention and Health promotion and a problematic level in the domain of Healthcare. Based on these results, it can be said that patients have some ability to process the information provided by the health professionals and that they use this information to make their therapeutic decisions. However, they are less able to understand the information related to coping with the risk factors and health determinants in order to promote their health and the health of those around them, as well as to correctly use the different health services depending on their needs. It should be emphasized that this study, although it was geographically limited 
(the area of coverage of a cluster of healthcare centers) and its sample had specificities resulting from the respondents' residence area, shows important similarities with the results of other studies (Davey, Holden, \& Smith, 2015; Espanha et al., 2016; Omachi, Sarkar, Yelin, Blanc, \& Katz, 2013). This similarity of results is of particular importance because it reveals the existence of a HL profile of Portuguese citizens, which calls for an effective strategy to empower patients to manage their care needs and health information effectively. It should be noted that, as in every other study, this study also had limitations, namely those related to the fact that data were collected from a sample living in a specific region with a small representation of the population. However, it should also be noted that these data can provide a significant contribution to the (re)definition of the HL promotion strategies of the health institution where the study was conducted.

According to the European Union Health Strategy, HL is a key principle for citizens' empowerment, stating that health care should be more individualized and patient-centered and that the patient should become an active subject rather than a mere object of healthcare. Promoting and increasing HL is the key to the vision of Europe 2020: a smart, inclusive, and sustainable development, which contributes to the social and economic cohesion of the countries of the European Union (European Commission, 2007).

In this study, patients with DM had higher HL levels than those with HT. This difference may be related to the fact that HT is a disease caused by risk behaviors, unlike DM, which, although it can be associated with risk behaviors, can result from an endocrine problem. It is expected that patients with DM have higher HL because DM is hard to keep under control. When comparing the HL level with the existence of other diseases besides those analyzed, the results showed that, although it was expected that people with more diseases had higher HL since they contact more often with the healthcare system (Davey et al., 2015), this situation was not true here. In this study, patients who only had DM or HT were the ones with higher HL level, although this difference was not statistically significant.
Recent studies point to the fact that patients with low HL levels are more prone to using healthcare services because they lack the confidence to manage their own health condition without health professionals' advice. Moreover, those patients who were being followed-up in a health unit had higher HL level, even though this result was not statistically significant.

Studies indicate that the doctor is the main source of information, that is, the first choice for clarifying doubts or obtaining health-related information, thus being the professional who most contributes to increasing patients' HL level (Espanha et al., 2016). In this sample, the results are in line with the overall scenario, given that the respondents also reported that doctors were the professionals who most contributed to increasing their $\mathrm{HL}$ level, followed by nurses.

\section{Conclusion}

People with a low HL level tend to have more complications associated with HT and DM both because disease control is more demanding and they have a clear lack of skills necessary for coping with the disease. Therefore, health professionals (especially nurses and doctors) should give particular attention to this group of people, providing them with management skills for meeting the demands of their diseases.

Without higher HL levels, Portugal will not be able to achieve the goals of a healthy European citizenship. For it to be possible, it is important to realize that low HL levels can have consequences not only for the citizens but also for the health systems and society in general.

Considering the limitations of the sample and the specific characteristics of this study, the results answered the research question, identifying a predominance of an inadequate or problematic HL level associated with the variables of gender (a sample mainly comprised of women), low education level, and patients with HT and DM. These results are in line with the available literature on the subject and underline the association between education level and HL level. Health profes- 
sionals should give special attention to this positive correlation because people with a low education level also have few information resources and are less able to act on the domains of Disease prevention and Health promotion. These data confirm the need for more health education programs designed according to the specificities of each population group and for each type of disease. The domains of Health promotion and Disease prevention are at an inadequate level, which translates into a lack of skills and knowledge to prevent possible diseases, which should be a priority area for health professionals.

The data resulting from this study represent an important contribution to better understanding HL, but this topic should remain at the center of academic, research, and policy-makers' agendas for them to proceed with the identification of regional and national profiles of HL in Portugal. This identification will allow understanding patients' health information and education needs in several areas related to treatment management and the relationship with health professionals, leading to the development of individualized therapeutic intervention strategies. To sum up, by identifying problematic HL levels among chronic patients in this ACeS, this study will also help managers to design appropriate intervention plans to fill this gap.

Further studies with other methodologies should also be conducted to analyze the multidimensional aspects of HL.

\section{References}

Costa, A., Saboga-Nunes, L., \& Costa, L. (2016). Avaliação do nível de literacia para a saúde numa amostra portuguesa. Boletim Epidemiológico Observaçôes, 5(17), 38-44. Retrieved from http://repositorio.insa. pt/bitstream/10400.18/4111/1/Boletim_Epidemiologico_Observacoes_N17_2016_artigo9.pdf

Davey, J., Holden, C. A., \& Smith, B. J. (2015). The correlates of chronic disease-related health literacy and its components among men: A systematic review. BMC Public Health, 15, 1-12. doi:10.1186/s12889-015-1900-5

Despacho no 3618-A/2016 de 10 de Março. Diário da República no 49/16 - II Série. Gabinete do Secretário de Estado Adjunto e da Saúde. Lisboa, Portugal.

Direção-Geral da Saúde. (2016). A saúde dos portugue- ses. Retrieved from https://www.dgs.pt/documentos-e-publicacoes/a-saude-dos-portugueses.aspx

Edwards, M., Wood, F., Davies, M., \& Edwards, A. (2015). Distributed health literacy: Longitudinal qualitative analysis of the roles of health literacy mediators and social networks of people living with a longterm health condition. Health Expectations, 18(5), 1180-1193. doi:10.1111/hex.12093

Espanha, R., Ávila, P., \& Mendes, R. (2016). Literacia em saúde em Portugal. Lisboa, Portugal: Fundação Calouste Gulbenkian.

European Commission. (2007). Together for health: A strategic approach for the EU 2008-2013. Retrieved from http://ec.europa.eu/health/ph_overview/Documents/ strategy_wp_en.pdf

Instituto Nacional de Estatística. (2011). Instituto nacional de estatistica. Retrieved from https://www.ine.pt/xpor$\mathrm{tal} / \mathrm{xmain}$ ?xpid=INE\&xpgid=ine_publicacoes\&PUBLICACOESpub_boui=149446932\&PUBLICACOESmodo $=2$

International Diabetes Federation. (2013). IDF diabetes atlas ( $6^{\text {th }}$ ed.). Brussels, Belgium: Autor.

Kale, M. S., Federman, A. D., Krauskopf, K., Wolf, M., O'Conor, R., Martynenko, M., ... \& Wisnivesky, J. P. (2015). The association of health literacy with illness and medication beliefs among patients with chronic obstructive pulmonary disease. PLoS One, 10(4), 1-10. Retrieved from http://journals.plos.org/plosone/ article/file?id=10.1371/journal. pone. $0123937 \&$ type=printable

Omachi, T. A., Sarkar, U., Yelin, E. H., Blanc, P. D., \& Katz, P. P. (2013). Lower health literacy is associated with poorer health status and outcomes in chronic obstructive pulmonary disease. Journal of General Internal Medicine, 28(1), 74-81. doi:10.1007/s11606012-2177-3

Pedro, A. R., Amaral, O., \& Escoval, A. (2016). Literacia em saúde, dos dados à ação: Tradução, validação e aplicação do European Health Literacy Survey em Portugal. Revista Portuguesa de Saúde Pública, 34(3), 259-275. Retrieved from http://www.elsevier.pt/pt/ revistas/revista-portuguesa-saude-publica-323/pdf/ S0870902516300311/S200/

Pereira, D. A., Costa, N. M., Sousa, A. L., Jardim, P. C., \& Zanini, C. R. (2012). Efeito de intervenção educativa sobre o conhecimento da doença em pacientes com diabetes mellitus. Revista Latino-Americana de Enfermagem, 20(3), 1-8. Retrieved from http://www.scielo. br/pdf/rlae/v20n3/pt_a08v20n3.pdf

Peterson, P. N., Shetterly, S. M., Clarke, C. L., Bekelman, D. B., Chan, P. S., Allen, L. A. ... Masoudi, F. A. (2011). Health literacy and outcomes among 
patients with heart failure. Journal of American Medical Association, 305(16),1695-1701. doi:10.1001/ jama.2011.512

Salazar, L. F., Crosby, R. A., \& DiClemente, R. J. (2015). Research methods in health promotion. San Francisco, CA: John Wiley \& Sons.

Santos, O. (2010). O papel da literacia em saúde: Capacitando a pessoa com excesso de peso para o controlo e reduçáo da carga ponderal. Observatório Nacional da Obesidade e do Controlo do Peso, 4(3), 127-134. Retrieved from https://dspace.uevora.pt/rdpc/bitstream/10174/2320/1/ (2010)\%20Literacia\%20em\%20sa\%C3\%BAde\%20 -\%20 capacitando $\% 20 \mathrm{a} \% 20$ pessoa $\% 20$ com $\% 20$ excesso $\% 20 \mathrm{de} \% 20$ peso $\% 20$ para $\% 20$ o $\% 20$ controlo\%20e\%20redu\%C3\%A7\%C3\%A3o\%20da $\% 20$ carga $\% 20$ ponderal.pdf

Serra, C. (2016). Três milhöes de portugueses são hipertensos. Retrieved from http://www.cmjornal.pt/sociedade/ detalhe/tres-milhoes-de-portugueses-sao-hipertensos
Soares, D., Viamonte, S., Magalhães, S., Ribeiro, M. M., Barreira, A., Fernandes, P., \& Torres, S. (2013). Que fatores determinam os níveis de atividade física após programa de reabilitaçáo cardíaca? Acta Médica Portuguesa, 26(6), 689-698. Retrieved from http://repositorio.chporto.pt/bitstream/10400.16/1638/1/Programa\%20de\%20Reabilita\%C3\%A7\%C3\%A3o.pdf

Sørensen, K., Brouke, S. V., Fullam, J., Doyle, G., Pelikan, J., Slonska, Z., Brand, H., \& Consortium Health Literacy Project European. (2012). Health literacy and public health: A systematic review and integration of definitions and models. BMC Public Health, 12, 1-13. doi:10.1186/1471-2458-12-80

Think Tank Capacitação do Cidadão em Saúde. (2015). Questionário europeu de literacia em saúde aplicado em Portugal: Apresentação dos resultados preliminares. Retrieved from http://pelorim.pt/ wp-content/uploads/2015/01/resultados-preliminares-HLS-EU-PT.pdf 